\title{
Cord Serum Bilirubin Level in Predicting the Development of Significant Hyperbilirubinemia in Newborns with $A B O$ Incompatibility
}

\author{
Arora $S^{1}$, Shifali $^{2}$
}

\begin{abstract}
Introduction: Neonatal hyperbilirubinaemia is common problem which is benign in majority of neonates. Rh iso immune hemolytic disease as a cause of hyperbilirubinemia is becoming nearly nonexistent due to the use of prophylactic anti D. Hence Isoimmune hemolytic disease due to $A B O$ incompatibility assumes significance as a cause of significant hyperbilirubinaemia. This study was conducted to determine the incidence of $A B O$ incompatibility, $A B O$ iso immune disease in new born, to determine critical cord serum bilirubin level to predict subsequent significant hyperbilirubinemia. Material and Methods: The study was done in neonatal ICU of a tertiary care hospital where 100 full term healthy newborns with B.W $\geq 2500$ gm and gestational age $\geq 37$ wk with blood group $A, B$, $A B$, born to mothers with $O$ blood group without simultaneous Rh incompatibility at SGRDIMSR were included. Serum bilirubin was measured approximately at $12-24 \mathrm{hrs}, 36-48 \mathrm{hrs}, 60$ $72 \mathrm{hrs}$. Results: Out $100 \mathrm{ABO}$ incompatible newborns 33(33\%) developed $A B O$ isoimmune disease manifesting as significant hyperbilirubinaemia with any of the four total serum bilirubin levels exceeding threshold levels defined for phototherapy. TSB of $\geq 2.16 \mathrm{mg} / \mathrm{d} 1$ from cord blood has a sensitivity of $100 \%$ specificity of $89.55 \%$, NPV $100 \%$ and PPV of $82.50 \%$ to predict significant hyperbilirubinaemia. Conclusion: A critical cord S.bilirubin between $2.16 \mathrm{mg} / \mathrm{d} 1$ and $4.09 \mathrm{mg} / \mathrm{d} 1$ will predict all newborns who will have significant hyperbilirubinaemia and can be used as a safe demarcator to decide time of discharge. Any therapeutic intervention if necessary can be started as early as possible.
\end{abstract}

Key words: Hyperbilirubinemia, Cord blood, Immune haemolytic disease, Bilirubin encephalopathy

\section{Introduction}

$\mathrm{N}$ eonatal hyperbilirubinaemia is common problem which is benign in majority of neonates. In the era of early discharge from the hospital, in view of increase work load and risk of nosocomial infection, there is increasing number of readmission of these neonates with significant hyperbilirubinaemia ${ }^{1}$. A reasonable strategy would be required to decrease incidence of severe hyperbilirubinaemia and bilirubin encephalopathy while minimizing risk of unintended
${ }^{1}$ Dr. Sunita Arora, MBBS.MD, Professor. ${ }^{2}$ Dr. Shifali, MBBS, MD Resident. Both from the Department of Paediatrics, Sri Guru Ram Das Institute of Medical Sciences and Research, Sri

Amritsar, Amritsar, India.

\section{Address for correspondence:}

Dr. Sunita Arora, Professor

Department of Paediatrics

Sri Guru Ram Das Institute of Medical Sciences and Research

Sri Amritsar, Amritsar, India

E-mail: dr.sunita1@yahoo.com

Tel: +91-9814710274

\section{How to cite}

Arora S, Shifali. Cord Serum Bilirubin Level in Predicting the Development of Significant Hyperbilirubinemia in Newborns with Abo Incompatibility. J Nepal Paediatr Soc 2015;35(3):231-236.

doi: http://dx.doi.org/10.3126/jnps.v35i3.13797

This work is licensed under a Creative Commons Attribution 3.0 License.

(c) (i)

harm such as maternal anxiety, decreasing breast feeding and unnecessary cost of treatment. $\mathrm{Rh}$ iso immune hemolytic disease is becoming nearly nonexistent due to the use of prophylactic anti D. Hence Isoimmune haemolytic disease due to $A B O$ incompatibility assumes significance as a cause of significant hyperbilirubinaemia.

Approximately $15 \%$ of live births are at increased risk but jaundice develops in only 0.3 to $2.2 \%^{2}$. Antibodies against $A$ and $B$ antigens are natural antibodies which occur without previous immunization. Most of these antibodies are Ig $\mathrm{M}$ type which do not cross placenta. However Ig $\mathrm{G}$ antibodies to $A$ or $B$ antigen may be present which can 
cross placenta. Thus $A B O$ iso immune hemolytic disease can be found in first born infants. Low antigenicity of $A$ and $B$ factors and the wide distribution in placenta and other body tissues apart from red cell accounts for relatively low incidence and milder nature of $A B O$ hemolytic disease ${ }^{3}$.

Presumptive diagnosis is based on the presence of $A B O$ incompatibility, elevated unconjugated serum bilirubin level, weakly to moderately positive DCT, spherocytosis in blood smear, increased number of nucleated red blood cells and increased reticulocyte count with marked polychromasia².

To target health care resources towards high risk newborns cord bilirubin, $1^{\text {st }}$ day bilirubin and pre discharge bilirubin values have been used to predict significant hyperbilirubinaemia in healthy term new born to keep a close follow up and plan intervention if needed $4,6,7,8,9$. These studies did not include $A B O$ or $\mathrm{RH}$ incompatibility. S.Bilirubin of $>6 \mathrm{mg} / \mathrm{dl}$ in first $24 \mathrm{hrs}$ was found to be the risk factor for significant hperbilirubinemia in healthy term newborn. Positive direct coombs test, high maternal IgG Anti A and Anti $B$, high reticulocyte count and a sibling with jaundice are all predictors of significant jaundice in $A B O$ incompatibility ${ }^{10,11}$. Six hour bilirubin levels of $4 \mathrm{mg} / \mathrm{dl}$ and $6 \mathrm{mg} / \mathrm{dl}$ are predictors for significant hyperbilirubinaemia and severe haemolytic disease of new born respectively, as highlighted by S Umit Sarci et al. ${ }^{12}$ End tidal carbondioxide measurement in direct antiglobulin test negative $A B O$ new born with significant jaundice points to a cause other than iso immunization.

This study was conducted to determine the incidence of $A B O$ incompatibility, $A B O$ iso immune disease in new born, to determine critical cord serum bilirubin level to predict subsequent significant hyperbilirubinemia and to evaluate correlation of laboratory markers of haemolysis and development of significant hyperbilirubinemia.

\section{Material and Methods}

This was a planned prospective hospital based follow up study of 15 months duration on 100 cases conducted in department of paediatrics in collaboration with department of pathology and biochemistry at Sri Guru Ram Das Institute of Medical Sciences and Research, Amritsar. A total of 100 healthy newborn with birth weight $\geq 2500$ gm and gestation $\geq 37$ wks with blood group $A, B, A B$ born to mother with blood group $\mathrm{O}$ without simultaneous $\mathrm{Rh}$ incompatibility were taken.
100 full term healthy newborns with $B . W \geq 2500$ gm and gestational age $\geq 37$ wk with blood group $A, B$, $A B$, born to mothers with $O$ blood group without simultaneous Rh incompatibility at SGRDIMSR from $1^{\text {st }}$ Feb 2012 to June 2013 were included. Hb, reticulocyte count, blood group ( $\mathrm{ABO}$ and $\mathrm{Rh}$ ), direct antiglobulin test, peripheral blood film, Serum bilirubin (total and direct) were performed in all cases from cord blood. Subsequently serum bilirubin was measured approximately at $12-24 \mathrm{hrs}, 36-48 \mathrm{hrs}, 60-72 \mathrm{hrs}$.

The exclusion criteria were; Sick newborns with respiratory distress, asphyxia, sepsis, major congenital anomalies, Rh incompatibility, Cephalhematoma and G6PD deficiency

Guidelines for phototherapy and exchange transfusion were according to recommendations of American Academy of Paediatrics ${ }^{13}$. Serum bilirubin measurement was done by Jendrassic and Grof method, Coombs test was performed using anti human globulin reagent, Glucose6 phosphate dehydrogenase estimation was done by dye decolorisation method.

Statistical analysis was done by software SPSS version 16 on completion of study.

Permission from the institutional ethical committee was taken before conductiong the study study.

\section{Results}

Out of total 608 term deliveries, 106 (17.4\%) were cases of $A B O$ incompatibility. Out $100 \mathrm{ABO}$ incompatible newborns 33(33\%) developed $A B O$ isoimmune disease manifesting as significant hyperbilirubinaemia with any of the four total serum bilirubin levels exceeding threshold levels defined for phototherapy.

Demographic characteristics like sex, mode of delivery, Birth weight, type of blood group incompatibility did not seem relevant to development of significant jaundice. O/A incompatibility was more common on the whole (50 Cases) but the difference in the two groups was statistically insignificant. DCT was negative in 31 newborn with significant hyperbilirubinaemia and all newborn without significant hyperbilirubinaemia. Two babies with positive DCT had significant jaundice, Difference in DCT positivity was statistically significant in two group with a $p$-value 0.042 . Difference in $\mathrm{Hb}$ value was not statistically significant in two groups. Difference in reticulocyte count was significant in two groups. 
Cord SB and subsequent serum bilirubin values were higher in significant hyperbilirubinemia group than non significant hyperbilirubinemia group and difference was statistically significant.

Predictive ability of cord serum bilirubin in determining development of significant hyperbilirubinemia was assessed on basis of hour specific percentile based nomogram.

If $35^{\text {th }}$ percentile is taken as cutoff value, even a single case of significant hyperbilirubinemia will not be missed but large number of newborns will be subjected to unnecessary investigation. Thus any serum biliirubin value below $35^{\text {th }}$ percentile constitutes low risk group. Values between $35^{\text {th }}$ and $60^{\text {th }}$ percentile constitutes low intermediate risk group. Cord serum bilirubin at or above $60^{\text {th }}$ percentile have a high probability of developing significant hyperbilirubinemia. As the sensitivity is $100 \%$ no neonate with significant jaundice will be missed. At the same time specificity is $90 \%$ and accuracy is $93 \%$. This constitutes high intermediate risk group. Cord serum bilirubin levels at or above $90^{\text {th }}$ percentile has specificity and positive predictive value of $100 \%$ but sensitivity of $30 \%$. Newborns having cord serum bilirubin at or above $90^{\text {th }}$ centile will definitely develop significant hyperbilirubinemia as specificity and PPV is $100 \%$ but we can miss upto $70 \%$ newborns who can develop significant jaundice because sensitivity is only $30 \%$.

Then it can be inferred that any newborn with serum bilirubin at or above $90^{\text {th }}$ percentile should not be discharged and the one between $60^{\text {th }}$ and $90^{\text {th }}$ percentile should be kept on close follow up.

TSB of $2.16 \mathrm{mg} / \mathrm{d} 1$ from cord blood has a sensitivity of $100 \%$ specificity of $89.55 \%$, NPV $100 \%$ and PPV of $82.50 \%$ to predict significant hyperbilirubinaemia. Thus any newborn with cord serum bilirubin between $2.16 \mathrm{mg} / \mathrm{d} 1$ to $4.090 \mathrm{mg} / \mathrm{d} 1$ should be kept in close supervision. Newborns with cord serum bilirubin more than $4.09 \mathrm{mg} / \mathrm{d} 1$ should not be discharged and S.Bilirubin should be repeated in next $24 \mathrm{hrs}$.

Table 1: Demographic characteristics of groups with and without significant hyperbilirubinaemia.

\begin{tabular}{|c|c|c|c|}
\hline \multirow[b]{2}{*}{ Demographic Characteristics } & Group-1 & Group -2 & \multirow[b]{2}{*}{$p$-value } \\
\hline & $\begin{array}{c}(n=3) \text { Significant } \\
\text { hyperbilirubinaemia }\end{array}$ & $\begin{array}{l}\text { ( } n=67 \text { ) No significant } \\
\text { hyperbilirubinaemia }\end{array}$ & \\
\hline $\operatorname{Sex}(M / F)$ & $19 / 14$ & $34 / 33$ & 0.520 \\
\hline Mode of Delivery (NVD/LSCS) & $14 / 19$ & $33 / 34$ & 0.520 \\
\hline \multicolumn{3}{|l|}{ Blood Group } & \multirow{4}{*}{0.266} \\
\hline O/A & 20 & 30 & \\
\hline O/B & 12 & 35 & \\
\hline $\mathrm{O} / \mathrm{AB}$ & 1 & 2 & \\
\hline Birth weight mean $\pm S D$ & $2870 \mathrm{gm} \pm 293 \mathrm{gm}$ & $2873 g m \pm 254 g m$ & 0.476 \\
\hline Negative (Direct-Coomb Test) & 31 & 67 & \multirow{2}{*}{0.042} \\
\hline Positive (Direct Coomb Test) & 2 & 0 & \\
\hline Heamoglobin gm/dl mean \pm SD (range) & $\begin{array}{c}16.24 \pm 1.83 \pm \\
(13.8-20.8)\end{array}$ & $\begin{array}{l}15.6 \pm 2.0 \pm \\
(9.1-19.1)\end{array}$ & 0.121 \\
\hline Reticulocyte count mean \pm SD (range) & $\begin{array}{c}2.77 \pm 0.60 \\
(1.4-4.0)\end{array}$ & $\begin{array}{l}1.95 \pm 0.32 \\
(1.2-2.80)\end{array}$ & $<0.001$ \\
\hline
\end{tabular}

Table 2: Sequential S.bilirubin values (mean $\pm S D)$ in two groups

\begin{tabular}{|l|c|c|c|}
\hline Serum Bilirubin & $\begin{array}{c}(\mathbf{n}=33) \text { Significant } \\
\text { hyperbilirubinamia }\end{array}$ & $\begin{array}{c}(\mathbf{n = 6 7 ) N o n ~ s i g n i f i c a n t ~} \\
\text { hyperbilirubinamia }\end{array}$ & $p$-value \\
\hline Cord blood & $\begin{array}{c}3.82 \pm 0.52 \mathrm{mg} / \mathrm{dl} \\
(3.82-5.20)\end{array}$ & $\begin{array}{c}1.66 \pm 0.45 \mathrm{mg} / \mathrm{dl} \\
(0.80-3.60)\end{array}$ & $<0.001$ \\
\hline 12-24hrs & $\begin{array}{c}8.45 \pm 2.22 \mathrm{mg} / \mathrm{dl} \\
(3.80-14.5)\end{array}$ & $\begin{array}{c}4.18 \pm 0.94 \mathrm{mg} / \mathrm{dl} \\
(0.60-7.20)\end{array}$ & $<0.001$ \\
\hline 36-48hrs & $\begin{array}{c}11.17 \pm 2.50 \mathrm{mg} / \mathrm{dl} \\
(7.80-18.1)\end{array}$ & $\begin{array}{c}6.77 \pm 1.05 \mathrm{mg} / \mathrm{dl} \\
(4.20-9.80)\end{array}$ & $<0.001$ \\
\hline 64-72hrs & $\begin{array}{c}11.81 \pm 2.63 \mathrm{mg} / \mathrm{dl} \\
(7.80-19.3)\end{array}$ & $\begin{array}{c}9.10 \pm 1.60 \mathrm{mg} / \mathrm{dl} \\
(5.20-13.5)\end{array}$ & $<0.001$ \\
\hline
\end{tabular}

Figure in parenthesis depict range 
Table 3: Sensitivity, Specificity, positive and negative predictive value at different percentile tracts

\begin{tabular}{|l|c|c|c|c|c|c|c|c|c|c|}
\hline & TP & FP & TN & FN & N & Sensitivity & Specificity & PPV & NPV & A \\
\hline $35^{\text {th }}$ percentile & 33 & 29 & 38 & 0 & 100 & 100 & 56.7 & 53.25 & 100 & 71 \\
\hline $60^{\text {th }}$ percentile & 33 & 7 & 60 & 0 & 100 & 100 & 89.55 & 82.50 & 100 & 93 \\
\hline $90^{\text {th }}$ percentile & 10 & 0 & 67 & 23 & 100 & 30.30 & 100 & 100 & 74.44 & 77 \\
\hline
\end{tabular}

( $T P=$ true positive, $F P=$ false positive, $T N=$ true negative, $F N=$ false negative, $P P V=$ positive predictive value, $N P V=$ negative predictive value, $A=$ accuracy)

Table 4 : Mean Cord and subsequent serum bilirubin values at $35^{\text {th }}, 60^{\text {th }}$ and $90^{\text {th }}$ percentile

\begin{tabular}{|c|c|c|c|}
\hline & $\mathbf{3 5}^{\text {th }}$ centile & $\mathbf{6 0}^{\text {th }}$ centile & $\mathbf{9 0}^{\text {th }}$ centile \\
\hline Cord bilirubin (T1) & 1.600 & 2.160 & 4.090 \\
\hline S.B at 12-24 hrs(T2) & 4.200 & 5.200 & 9.850 \\
\hline S.B at 36-48 (T3) & 6.800 & 8.060 & 12.850 \\
\hline S.B at 60-72 (T4) & 8.835 & 10.320 & 12.400 \\
\hline
\end{tabular}

Risk designation according to percentile tracks based on age specific serum bilirubin values

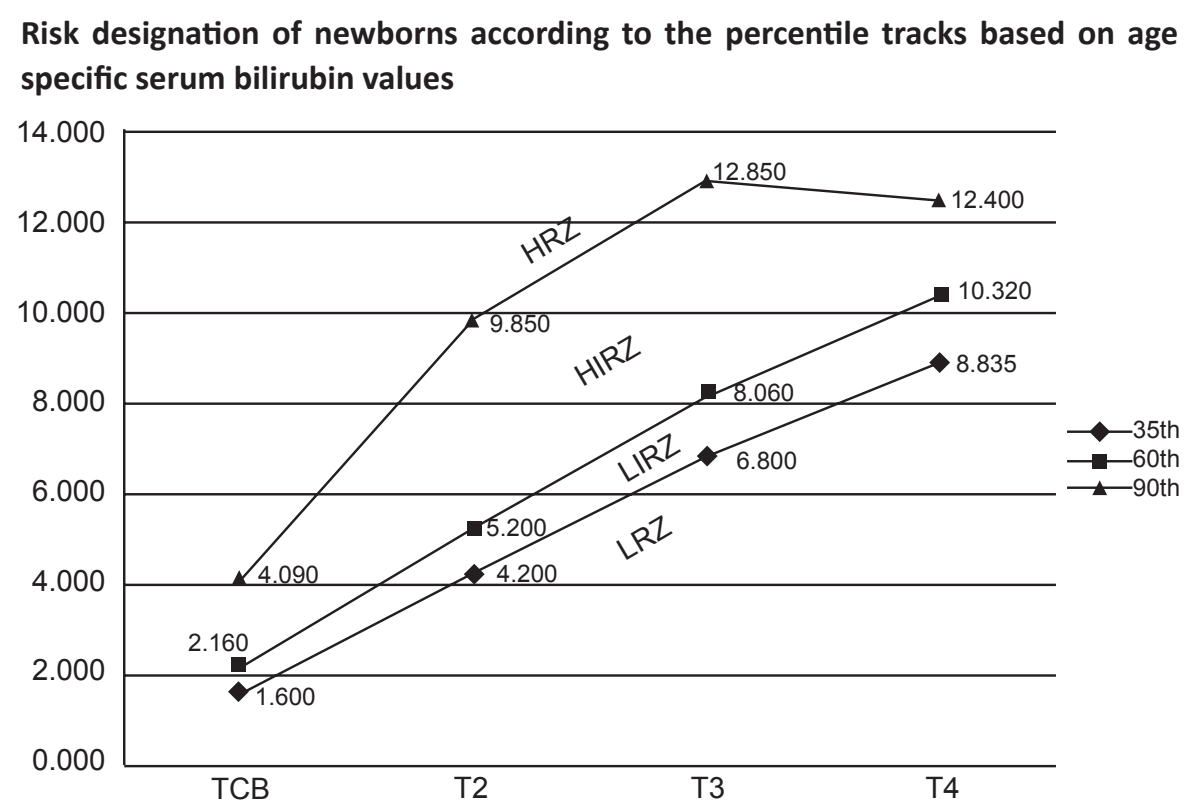

HRZ - high risk zone designed above the $90^{\text {th }}$ percentile tract.

HIRZ - high intermediate risk zone between $60^{\text {th }}$ and $90^{\text {th }}$ percentiles.

LIRZ - low intermediate risk zone between $35^{\text {th }}$ and $60^{\text {th }}$ percentiles.

LRZ - low risk zone below $35^{\text {th }}$ percentile track.

\section{Discussion}

Clinical course and severity of subsequent hyperbilirubinaemia or isommune disease is difficult to predict in a newborn with $\mathrm{ABO}$ incompatibility because there is no single test that is of high predictive value ${ }^{15,16}$.

Incidence of $\mathrm{ABO}$ incompatibility was $17.4 \%$ and significant jaundice was observed in 33\% of $A B O$ incompatible newborns in the present study. $\mathrm{HM}$ Rusemerg et al reported ABO incompatibility in 20-25\% of deliveries and $\mathrm{ABO}$ haemolytic disease in less than $10 \%$ of these cases ${ }^{9}$.
$S$ Umit et al reported $A B O$ incompatibility in $14.18 \%$ of deliveries out of which $21.3 \%$ had significant hyperbilirubinaemia ${ }^{12}$. Gender and mode of delivery does not seem to have any bearing on severity of jaundice. Thus all new borns should be considered for screening irrespective of sex and mode of delivery. This was consistent with observations of S Umit et al $^{12,17}$ and Frauk Aplay et $\mathrm{al}^{4}$. Type of ABO incompatibility did not determine the development of significant jaundice.O-A setting was observed in 20 and O-B in 12 newborns in significant hyperbilirubinaemia group. Similar observation were made by $\mathrm{S}$ Umit et al who observed O-A incompatibility in 21 and O-B in 8 newborns in hyprebilirubinaemia group ${ }^{12}$. 
Birth weight did not have any bearing on the development of significant jaundice. Mean birth wt. was2870 $\pm 305 \mathrm{gm}$ in significant hyperbilirubinemia group Vs $2873 \pm 254 \mathrm{gm}$ in non significant hyperbilirubinemia group. Frauk Aplay et al reported $3310 \pm 305 \mathrm{gm}$ Vs $3240 \pm 34 \mathrm{gm}$ in hyperbilirubinaemia and non hyprebilirubinaemia group respectively. ${ }^{4}$

S Umit Sarici et al reported birth weight of $2794 \pm 418 \mathrm{gm}$ and $2772 \pm 157 \mathrm{gm}$ in two groups. ${ }^{17}$

$S$ Umit et al observed mean birth weight of $3214 \pm 828 \mathrm{gmgm}$ and $3212 \pm 196 \mathrm{gm}$ in two groups ${ }^{12}$.

In present study only two babies had weakly positive DCT but both developed significant hyperbilirubinaemia requiring intensive phototherapy with peak serum bilirubin of $23 \mathrm{mg} / \mathrm{d} 1$ and $16.5 \mathrm{mg} / \mathrm{d} 1$ respectively. Thus DCT positivity predicts development of serve hemolytic disease of newborn.

S Umit et al detected positive DCT in 6 out of 29 newborns who developed hyperbilirubinaemia. All required intensive phototherapy and one required change trasfussion ${ }^{12}$.

H.M. Risemberg et al al noted a strong association of strongly positive coombs test with hyperbilirubinaemia in $A B O$ incompatibilty ${ }^{9}$. In Moderately affected group 9 (60\%) were DCT positive out of total 15 babies. Coomb test positivity was $15 \%$ in the group who did not develop significant hyperbilirubinaemia. They concluded that DCT is not itself a method to predict hyperbilirubinaemia. Marguerite Herschel et al opined that in $A B O$ incompatible newborns who are DCT negative with significant hyperbilirubinaemia, a cause other then isommunisation should be sought like G6PD def., Elliptocytosis, Gilibert syndrome etc ${ }^{14}$.

Cord blood haemoglobin cannot be relied upon to predict subsequencet development of hyprebilirubinaemia.This was in concordance with observation of S Umit al ${ }^{12}$.

We observed statistically significant difference in reticulocyte count in two group $(2.77 \pm 0.60 \%$ in group I versus $1.95 \pm 0.32$ in group 2). S Umit et al highlighted predictive values of high reticulocyte count for devolpement of significant hyperbilirubinemia. They observed a reticulocyte count of $4.39 \pm 3.446$ in hyperbilirubinemia group ${ }^{12}$.

Mean serum bilirubin in cord blood and subsequent 3 days' serum bilirubin was significantly higher in significant hyperbilirubinemia group as compared to other group. This was in concordance with observation made by $\mathrm{S}$ umit et $\mathrm{al}^{12}$.

In our study on constructing a percentile based nomogram based on age/hour specific serum bilirubin levels it was observed that cord serum bilirubin of $2.16 \mathrm{mg} / \mathrm{dl}$ at $60^{\text {th }}$ percentile curve has sensitivity, specificity, NPV and PPV of 100\%,91.5\%,100\% and $35.3 \%$ respectively. It has a high predictive value for subsequent hyperbilirubinemia requiring intervention.Cord serum bilirubin $\geq 60$ percentile constitutes high intermediate risk group and value $\geq 90^{\text {TH }}$ percentile $(4.09 \mathrm{mg} / \mathrm{dl})$ constitutes high risk group which is good predictor of developing severe hyperbilirubinaemia requiring extensive phototherapy or other appropriate intervention. Two babies in this category had positive DCT and developed severe haemolytic disease of new born.

Risemberg observed a strong association of cord serum bilirubin of $\geq 4 \mathrm{mg} / \mathrm{dl}$ with severe hyperbilirubinemia requiring exchange transfusion necessitating their placement in centre where frequent evaluation and appropriate therapy are available ${ }^{9}$. Robinsn et. al reported association of $A B O$ disease with cord S.bilirubin levels above $3 \mathrm{mg} / \mathrm{dl}^{18}$.

Similar observation was made by chen JY,ling UP who suggested that $A B O$ incompatible babies with cord $s b \geq 4 \mathrm{mg} / \mathrm{dl}$ or positive DCT constitute a high risk category ${ }^{10}$.

S Umit et $\mathrm{al}^{12}$ in their study of 136 healthy term newborns with $A B O$ incompatibility observed that mean $\mathrm{SB} \geq 4 \mathrm{mg} / \mathrm{dl}$ at $6 \mathrm{hrs}$ of life had sensitivity 86.2\%, NPV $94.5 \%$ and PPV $39.7 \%$ and $6 \mathrm{mg} / \mathrm{dl}$ had sensitivity specificity NPV and PPV 100\%,91.5\%,100\% and $35.3 \%$ respectively. Using percentile curves, they observed that $35^{\text {th }}$ and $90^{\text {th }}$ percentile curves approx. 3.3 and $6 \mathrm{mg} / \mathrm{dl}$ at $6 \mathrm{hrs}$ of life can be taken as safe risk demarcators to plan a time of discharge for $A B O$ incompatible newborn.

\section{Conclusion}

No statistically significant difference was observed in two groups regarding various demographic characteristics like sex, birth weight, feedings and mode of delivery and type of $A B O$ incompatibility. Cord serum bilirubin, reticulocyte count and positive DCT could serve as good predictors for development of subsequent hyperbilirubinaemia and severe hemolytic disease of newborn in $A B O$ incompatibility. It was also inferred that newborn with cord serum bilirubin $<2.16 \mathrm{mg} / \mathrm{d} 1$ were not at risk of developing 
significant hyperbilirubinaemia. Thus to conclude a critical cord S.bilirubin between $2.16 \mathrm{mg} / \mathrm{d} 1$ and $4.09 \mathrm{mg} / \mathrm{d} 1$ could predict all newborns who would have significant hyperbilirubinaemia and could be used as a safe demarcator to decide time of discharge. Any therapeutic intervention if necessary can be started as early as possible.

Acknowledgements: None

Funding: Nil

Conflict of Interest: None

Permission from IRB: Yes

\section{References}

1. American Academy of Pediatrics Subcommittee on Hyperbilirubinemia.Management of hyperbilirubinemia in the newborn infant 35 or more weeks of gestation. Pediatrics. 2004 Jul;114(1):297-316.

2. Barbaba JS. Blood Disorders. In:Kleigman,Behrman ,Janson,Stanton. Nelson textbook of pediatrics.18 ${ }^{\text {th }}$ ed.Philadelphia,PA;WB Saunders 2008:772.

3. Singh M.In: Care of newborn. $6^{\text {th }}$ ed.2004:244-45.

4. Alpay F, Sarici SU, Tosuncuk HD, Serdar MA, Inanç $N$, Gökçay E.The value of first-day bilirubin measurement in predicting the development of significant hyperbilirubinemia in healthy term newborns. Pediatrics 2000;106(2):E16.

5. Soskolne El, Schumacher R, Fyock C, Young $M L$, Schork A.The effect of early discharge and other factors on readmission rates of newborns. Arch Pediatr Adolesc Med 1996;150(4):373-9.

6. Bhutani VK, Johnson LH, Sivieri EM, Nadelson A, Dworanczyk R, Spitz DM et al. Universal newborn bilirubin screening. Pediatric Res 1997;41:191.

7. Seidman DS, Ergaz Z, Paz I, Laor A, Revel-Vilk S, Stevenson DK, Gale R. Predicting the risk of jaundice in full-term healthy newborns: a prospective population-based study. J Perinatol 1999;19(8 Pt 1):564-67.

8. Bhutani VK, Johnson L, Sivieri EM.Predictive ability of a predischarge hour-specific serum bilirubin for subsequent significant hyperbilirubinemia in healthy term and near-term newborns. Pediatrics 1999;103(1):6-14.
9. Risemberg HM, Mazzi E, Macdonald MG, Peralta $M$, Freidrick Heldrich. Correlation of cord bilirubin levels with hyperbilirubinemia in $A B O$ incompatibility. Arch Dis Child 1977;52:219-22.

10. Chen JY, Ling UP.Prediction of the development of neonatal hyperbilirubinemia in $A B O$ incompatibility. Zhonghua Yi Xue Za Zhi (Taipei) 1994;53(1):13-8.

11. Madlon-Kay DJ'The clinical significance of ABO blood group incompatibility. Arch Fam Med 1993;2(3):285-7.

12. Sarici SU, Yurdakök M, Serdar MA, Oran O, Erdem G, Tekinalp G, Yiğit S.An early (sixth-hour) serum bilirubin measurement is useful in predicting the development of significant hyperbilirubinemia and severe $A B O$ hemolytic disease in a selective high-risk population of newborns with $A B O$ incompatibility. Pediatrics 2002;109(4):e53.

13. Mary Lucia P Gregory, Camilla R Martin,John $P$ Cloherty In.Manual Of Neonatal Care, $7^{\text {th }}$ ed 2013.322.

14. Herschel $M$, Karrison $T$, Wen $M$, Caldarelli $\mathrm{L}$, Baron B.Isoimmunization is unlikely to be the cause of hemolysis in ABO-incompatible but direct antiglobulin test-negative neonates. Pediatrics 2002;110(1 Pt 1):127-30.

15. Whytw J, Graham H. Prediction of severity of $A B O$ hemolytic disease of newborn by cord blood tests. Acta Pediatr Scand 1981;70:217-22.

16. Levine DH, Meyer HB.Newborn screening for ABO hemolytic disease. Clin Pediatr (Phila) 1985;24(7):391-4.

17. Sarici SU, Serdar MA, Korkmaz A, Erdem G, Oran O, Tekinalp G, Yurdakök M, Yigit S.Incidence, course, and prediction of hyperbilirubinemia in near-term and term newborns. Pediatrics 2004;113(4):77580.

18. Robinson GC, Dunn HH, Wong LC. Part III: Clinical and laboratory findings in hetero-specific pregnancy with a note on the incidence of $A B O$ hemolytic disease. Acta Paediatrica 1960;49(120): 53-62. doi: 10.1111/j.1651-2227.1960.tb05938.x 